\title{
MESIN PERONTOK TANGKAI LADA BERKAPASITAS PRODUKSI 40 KG PER JAM
}

\author{
Sugianto ${ }^{1)}$, Sukanto ${ }^{2)}$ \\ 1) Prodi Teknik Perancangan Mekanik, Polman Negeri Bangka Belitung \\ ${ }^{2)}$ Prodi Perawatan dan Perbaikan Mesin, Polman Negeri Bangka Belitung \\ Jl. Air Kantung Sungailiat Bangka, Pos : 33211, Phone 0717 93586, Indonesia \\ Email: sugianto@polman-timah.ac.id
}

\begin{abstract}
Abstrack: The process shedding is still less effective until now, especially in Bangka-Belitung. The peppers which has been harvested be collected into the sack, after that it is continued to the process of soaking, washing and drying. In fact, it is less efficient because of the collected peppers are still with their stalks. The pepper thresher machine is a rubber roller construction machine system, which in tied up in the thresher shaft. This machine is operated with an electric motor. It is expected that this machine can help the farmer in case of the pepper collecting and decrease the sacks need. One hectare area of peppers agriculture planting have 2.500 peppers tree and they can produces 200 sack peppers before fall off by the stalk. The soaking process of peppers wich stalk peppers together having a need off many sacks. For two hundreds sack pepper with stalk only use 130 sack on peppers without stalk. So the process increase efficiency of using sack until achievement about $30 \%$.
\end{abstract}

Key words : peppers, sacks, rubber and soaking.

\section{PENDAHULUAN}

\subsection{Latar Belakang}

Lada telah dikenal diseluruh dunia sebagai rajanya rempah-rempah "King of Spice". Di Indonesia lada terutama dihasilkan di Pulau Bangka, lada disebut sahang dalam bahasa melayu lokal. Lada atau merica (Paper Ningrum L), adalah salah satu rempah penting dan memiliki berbagai khasiat obat. Hasil pengolahan lada ada beberapa jenis yaitu Lada hitam (Black Pepper), Lada putih(White Pepper), Lada hijau(Green Pepper), Lada jingga(Orange Pepper) dan Lada merah(Red Pepper). Dari beberapa jenis olahan lada tersebut, yang lebih dikenal hanya Lada hitam(Black Pepper) dan Lada putih(White Pepper). Untuk hasil olahan lada dari Propinsi Lampung dikenal dengan sebutan lada Black Paper dan hasil olahan lada dari Propinsi Kepulauan Bangka Belitung dikenal dengan sebutan Muntok White Paper. Sebutan tersebut dikenal karena indonesia merupakan salah satu produsen terbesar didunia.(Sumber: http://www.tanaman.bu didaya/lada.html).

Hasil survei yang telah dilakukan di daerah Bangka, para petani kurang efisien dalam memanfaatkan karung, dikarenakan masih terdapat banyak tangkai lada yang belum dirontokkan. Satu hektar lahan memuat sekitar 2.500 pohon lada dan dapat menghasilkan lada sebelum dirontokkan sebanyak 200 karung. Satu kg lada belum dirontokkan menghasilkan kurang lebih 7 ons biji lada siap direndam 
dan tangkainya mencapai 3 ons. Bila berat jenis tangkai lada dan buah lada sama maka karung yang diperlukan menampung buah lada sudah dirontokkan hanya perlu sekitar 130 buah karung atau terjadi efisiensi pemakaian karung sebesar $30 \%$ ketika proses perendaman. Tulisan ini menyampaikan pembuatan mesin perontok tangkai lada untuk memudahkan petani merendam biji lada, sehingga penggunaan karung dapat lebih hemat.

\subsection{Tinjauan Pustaka}

\subsubsection{Lada}

Lada (Piper nigrum L.) adalah jenis tanaman merambat dalam keluarga Piperaceae. Dari tanaman lada yang diambil adalah buahnya kemudian dikeringkan dan digunakan sebagai perlengkapan bumbu. Buah lada kering berdiameter sekitar $5 \mathrm{~mm}$. Berwarna merah tua saat matang penuh. Merica bubuk berasal dari penggilingan buah lada kering.Tanaman lada adalah jenis tanaman merambat yang dapat tumbuh empat meter dengan bertopang pada pohon atau tiang. Lada dapat tumbuh baik pada ketinggian kurang dari 3000 kaki di atas permukaan laut.Tanaman lada diperbanyak dengan stek sekitar 40 sampai $50 \mathrm{~cm}$ panjang, diikat ke tiang atau pohon sebagai tempat merambatnya. Tanaman berbuah pada tahun keempat atau kelima dan biasanya terus berbuah selama tujuh tahun. Satu batang tanaman lada akan menghasilkan 20 sampai 30 rumpun buah. Panen dimulai setelah satu atau dua buah didasar dari rumpun mulai berubah menjadi merah. Apabila terlambat dan buah sudah matang, buah lada akan berkurang kepedasannya.

\subsubsection{Jenis dan pengelompokkan lada}

Lada putih dibuat dari merica tua yang dikeringkan dan dikupas kulitnya, paling banyak digunakan sebagai bumbu dapur. Lada hitam, diperoleh dari lada yang tidak terlalu tua. Setelah dipetik dikeringkan dengan kulitnya sehingga permukaannya keriput dan kehitaman. Lada merah adalah sejenis lada dengan warna merah. Rasanya tidak terlalu pedas dan agak manis. Biasanya digunakan bersamaan dengan jenis merica yang pedas, cocok untuk olahan seafood dan dijual dalam bentuk segar dan kering. Lada hijau adalah lada yang dipetik saat belum terlalu tua dan warnanya masih kehijauan. Lada Szechuan, beda dengan lada pada umumnya. Jenis ini butirannya lebih kecil, aroma dan rasanya tidak terlalu tajam.

\subsubsection{Pengolahan lada}

Pengelolaan lada hingga saat ini masih dilakukan secara tradisional yaitu meliputi proses pemetikan, perendaman, pencucian, dan pengeringan. Lada yang sudah dipetik dikumpulkan ke dalam karung. Karung yang telah penuh selanjutnya direndam, pada tahap inilah penulis mencoba membuat mesin perontok lada dengan tujuan mengurangi jumlah pemakaian karung, sehingga lebih efisien. Selanjutnya para petani lada 
melakukan proses perendaman lada pada air mengalir selama 10-14 hari, kemudian lada yang telah direndam dicuci bersih hingga yang tersisa adalah biji lada itu sendiri, selanjutnya dijemur selama 3-4 hari.

\subsubsection{Proses Perancangan Mesin Perontok Lada \\ Perancangan produk}

Perancangan adalah kegiatan awal dari suatu rangkaian kegiatan dalam proses pembuatan produk. Kegiatan perancangan meliputi; didapatkannya persepsi tentang kebutuhan manusia, penciptaan konsep produk, perancangan, pengembangan dan penyempurnaan produk serta diakhiri pembuatan dan pendistribusian produk.Definisi Perancangan Sistem Menurut George M. Scott dalam buku Jogiyanto HM tahun 1991 halaman 196 adalah;

'Desain sistem menentukan bagaimana suatu sistem akan menyelesaikan apa yang mesti diselesaikan, tahap ini menyangkut mengkonfigurasikan dari komponen-komponen perangkat lunak dan perangkat keras dari suatu sistem sehingga setelah instalasi dari sistem akan benar-benar memuaskan rancang bangun yang telah ditetapkan pada akhir analisis system'. (Jogiyanto HM, 1991: 196 ).

\section{Fase-fase dalam proses perancangan}

Perancangan terdiri dari serangkaian kegiatan yang berurutan, karena itu perancangan kemudian disebut sebagai proses perancangan yang mencakup seluruh kegiatan yang terdapat dalam perancangan tersebut. Rangkaian kegiatan dalam proses perancangan dinamakan fase. Fase-fase dalam proses perancangan bisa berbeda satu dengan yang lainnya. Setiap fase masih terdiri dari beberapa kegiatan, yang dinamakan langkahlangkah dalam fase. Salah satu deskripsi proses perancangan adalah deskripsi yang menyebutkan bahwa proses perancangan terdiri dari fase-fase yang meliputi; identifikasikannya kebutuhan, analisis masalah, spesifikasi produk dan perencanaan proyek, perancangan konsep produk, perancangan produk, evaluasi produk hasil rancangan dan penyusunan dokumen berupa gambar produk hasil rancangan dan spesifikasi pembuatan produk.

\section{METODE PENELITIAN}

Metode pelaksanaan pemecahan masalah pada paper ini menggunakan pendekatan metodologi experimental dengan alur flow chartdibawah ini, dilakukan sebagai pedoman dalam menentukan tindakan, agar tindakan yang dilakukan lebih terarah dan tidak terjadi penyimpangan dari target yang diharapkan. 


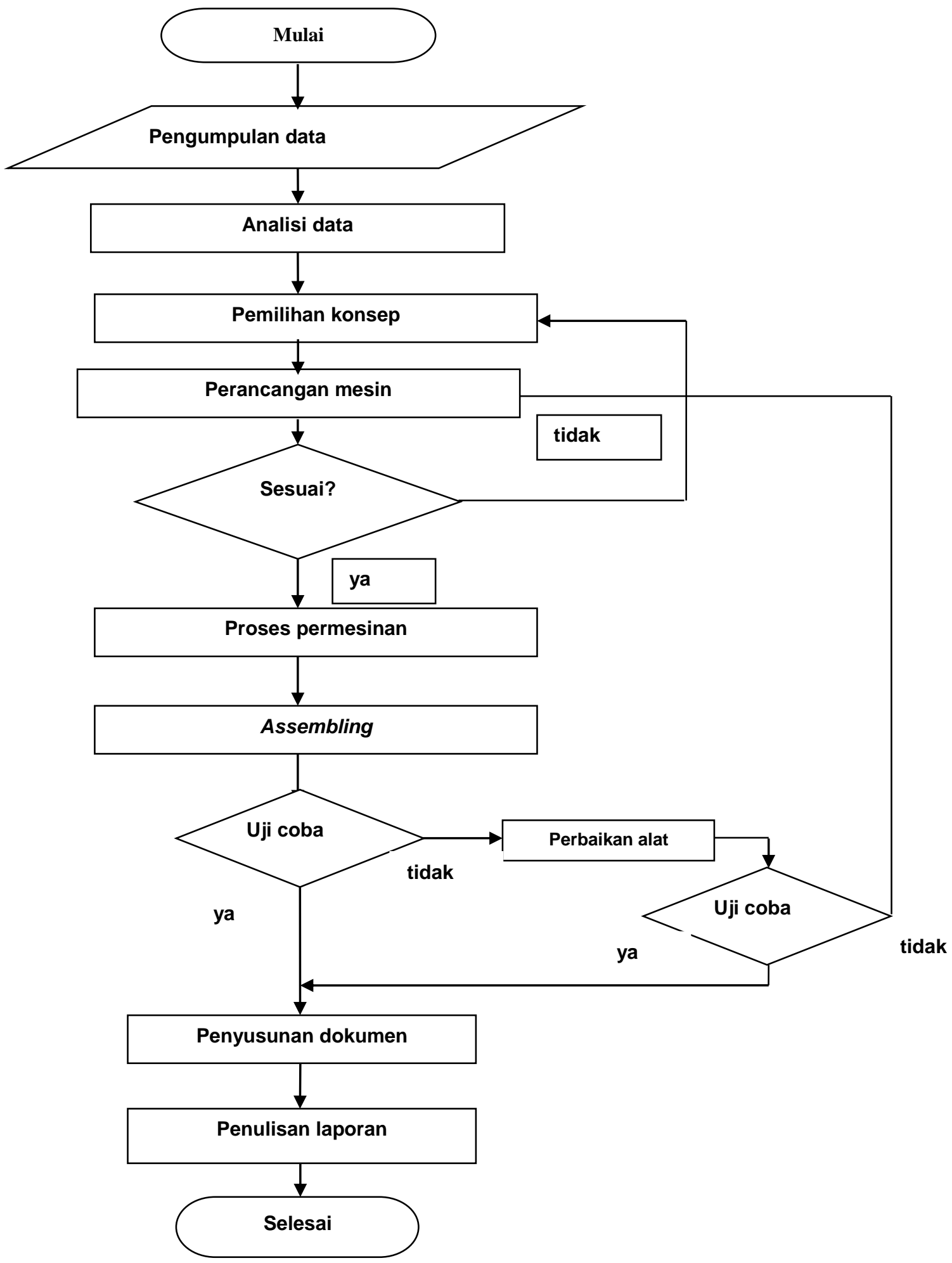

Gambar 2.1 Flow Chart metode penelitian 
Pengumpulan data dilakukan dengan beberapa metode yang bertujuan untuk mendapatkan data-data yang mendukung untuk pembuatan mesin perontok lada, meliputi kepustakaan, observasi (pengamatan langsung) ke lapangan, wawancara pada para petani lada dan pengumpulan informasi melalui internet untuk menambah dan melengkapi alternatif solusi yang akan ditawarkan.

Daftar tuntutanmenguraikantuntutan yang ingin dicapai dari produk yang dibuat, misalnya: Kapasitas, Dimensi dan Kemudahan dalam produks yang diharapkani. Didalam merancang sebuah alat terlebih dahulu diketahui fungsi sistem yang digunakan pada produk tersebut dibahas pada analisa fungsi bagian. Sedangkan Alternatif fungsi bagian membahas tentang ada berapa alternatif fungsi bagian yang dapat digunakan. Untuk memudahkan dalam memilih alternatif, dilakukan penilaian dan untuk mendapatkan alternatif yang optimal, perlu dibuat skema penilaian. Setiap alternatif harus memiliki pemecahan masalah yang berbeda, tetapi batasan tuntutan yang diinginkan pada suatu produk tetap harus dipenuhi. Adapun penilaiannya dengan angka, seperti pada tabel 2.1.

Tabel 2.1 Bobot Penilaian

\begin{tabular}{|c|c|}
\hline Kriteria penilaian & Nilai angka \\
\hline Sangat kurang & 1 \\
\hline Kurang & 2 \\
\hline Cukup & 3 \\
\hline Baik & 4 \\
\hline Sangat Kurang & 5 \\
\hline
\end{tabular}

Kemudian dapat disimpulkan bahwa :

Alternatif pemecahan yang dipilih mendapat nilai tertinggi.

Alternatif pemecahan yang tidak dipilih mendapat nilai terendah.

Pembuatan konsep produkakan dibayangkan mesin yang sesuai dengan spesifikasi dan merealisasikan rancangan tersebut dalam bentuk kasar dan dibuat sket pada kertas.Sedangkan analisa perhitungan akan menganalisis perhitungan yang menyangkut dengan sistem perancangan. Pada pembuatan gambar draft merupakan pembentukan konsep dalam gambar sket yang dipilih dan menggambarkan sistem mekanisnya, ukuran, dan sistem pembuatan yang disesuaikan dengan fasilitas di bengkel.Pembuatan gambar kerja dikerjakan dengan menerjemahkan informasi yang ada dalam gambar draft .

Proses pembuatan mesin perontok lada dilakukan di bengkel mekanik Polman Negeri Babel. Adapun proses permesinannya dilakukan di mesin bubut, mesin bor dan mesin las dengan mengikuti tahapan-tahapan dan prosedur permesinan yang telah dibuat dalam suatu rancangan gambar.Perakitan adalah suatu proses menggabungkan part-part menjadi suatu alat atau mesin yang sudah dirancang sesuai dengan tahapan-tahapan proses yang telah ditentukan sehingga hasil yang diinginkan bisa tercapai. Proses perakitan biasanya menggunakan proses-proses permesinan misalnya proses pengelasan antara rangka-rangka, proses pengeboran lubang untuk baut yang digunakan untuk melekatkan antara part yang satu dengan yang lain.

\section{HASIL PENELITIAN DAN PEMBAHASAN \\ 2.1. Perencanaan dan Metode pengumpulan data}

Dari pernyataan permasalahan yang ada yaitu proses pengumpulan lada masih dirasakan kurang efisien dalam pemanfaatan tempat dan biaya yang dikeluarkan dan sesuai dengan keinginan konsumen maka penulis akan mencoba untuk merancang mesin perontok tangkai 
lada sederhana yang dapat digunakan oleh industri kecil menengah kebawah. Pengumpulan data dilakukan dengan beberapa metoda, diantaranya yaitu dengan penyebaran quisioner, interview, serta dokumentasi. Data yang diambil dari petani pengumpul lada ditunjukkan dalam quisioner, dengan hasil bahwa mesin perontok tangkai lada ini sangat dibutuhkan.

\subsection{Perancangan}

Tujuan perancangan suatu mesin adalah membuat sesuatu yang baru dengan pertimbangan mesin yang dirancang bernilai ekonomis baik dari biaya produksi maupun cara pengoperasiannya. Proses perancangan diperlukan pengetahuan yang baik tentang kekuatan bahan, teori permesinan dan proses permesinan.Dari permasalahan yang ada, maka akan dirancang dan dibuat suatu prototipe mesin perontok tangkai lada yang sederhana dan dapat merontok lada menjadi terpisah dari tangkainya.

\section{Analisa fungsi bagian}

Mesin perontok lada ini menggunakan energi listrik dan material masukan berupa lada segar yang masih terdapat tangkainya. Keluaran dari mesin tersebut berupa panas, getaran, butiran lada dan sisa tangkai yang terontok.

Berikut adalah gambar blok fungsi dari Mesin perontok tangkai lada:

\section{Daftar tuntutan}

Tabel 3.1. Daftar Tuntutan

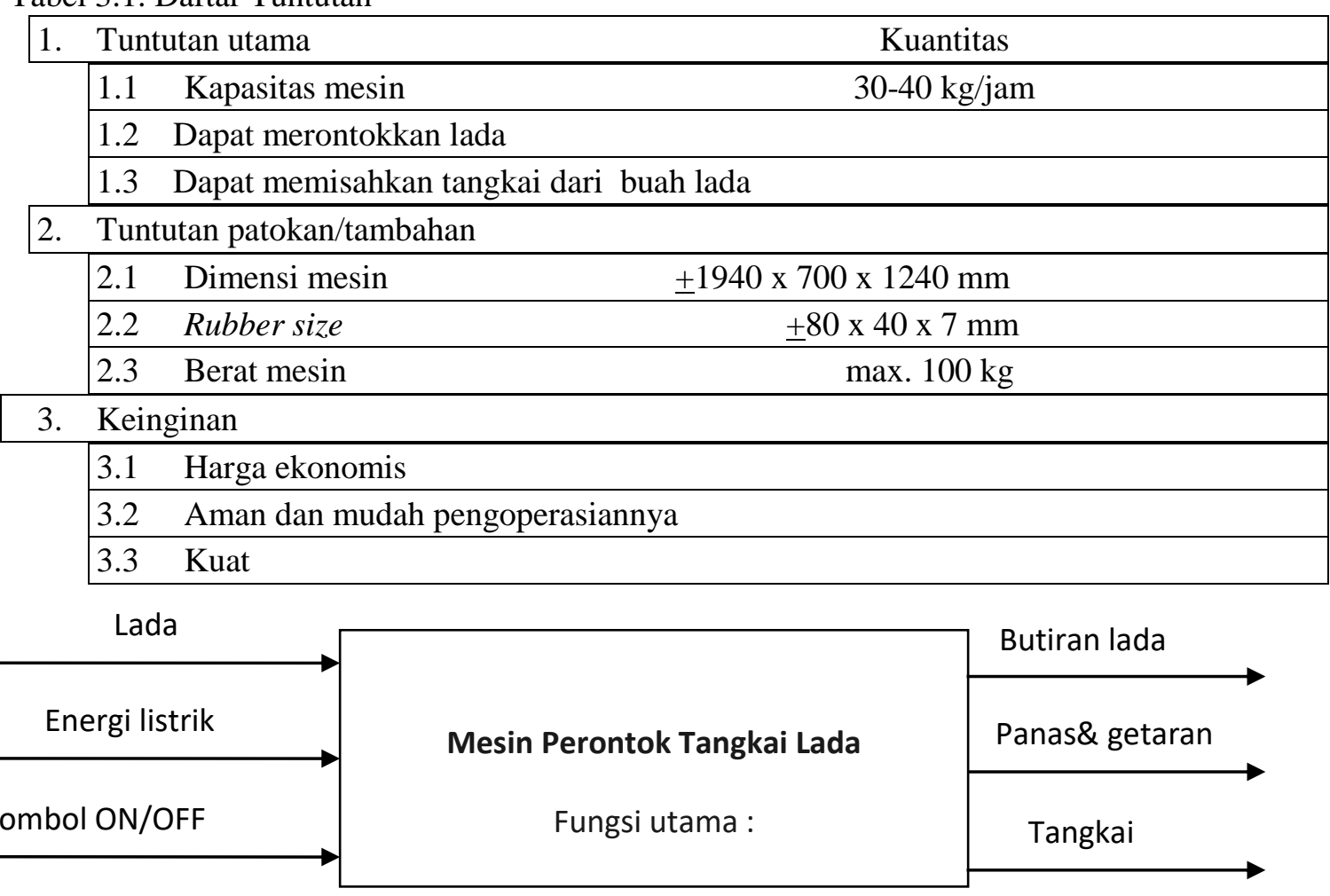

Gambar 3.1 Blok fungsi 


\section{Alternatif fungsi bagian}

Dalam pemilihan alternatif setiap sistem, penulis hanya membahas pemilihan alternatif untuk poros perontok dan sistem penggeraknya saja. Berikut tabel pemilihan alternatif dengan 3 (tiga) alternatif yang memiliki kriteria yang berbeda-beda.

Tabel 3.2 Alternatif sistem perontok

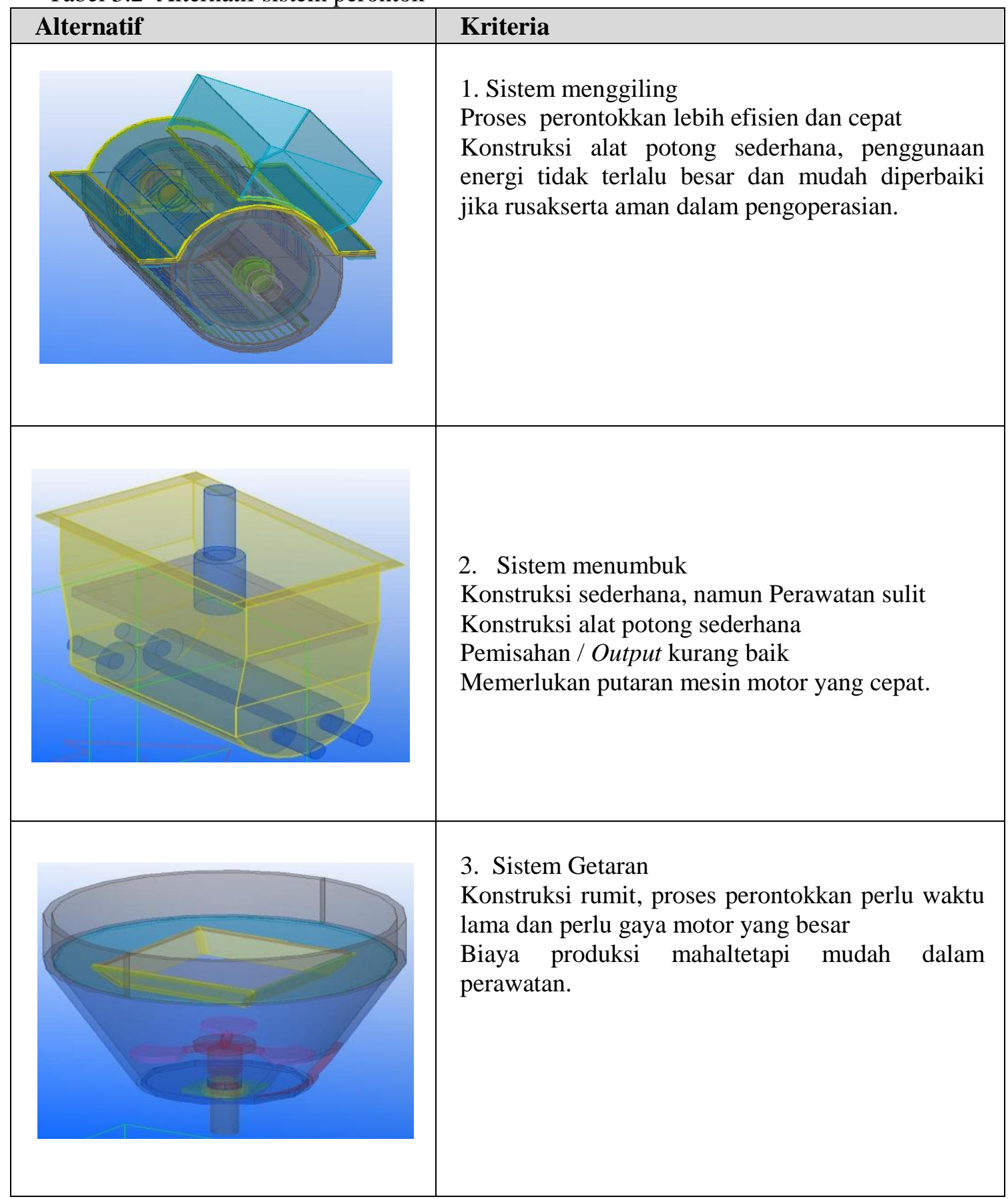




\section{Pemilihan alternatif sistem rol}

Pemilihan akternatif dari sistem yang dipilih disesuaikan dengan ujicoba yang telah dilakukan melalui prototipe sederhanaseperti yang tampak pada tabel 3.3 .

Tabel 3.3 Alternatif sistem roll

\begin{tabular}{|l|l|l|}
\hline a. konstruksi dengan 1 buah rol & b. konstruksi dengan 2 buah rol \\
\hline
\end{tabular}

\section{a. Konstruksi dengan 1 buah roll}

Alternatif konstruksinya satu buah rol dan memanfaatkan gaya gesek yang terjadi pada poros dan pelat setengah lingkaran yang dipasang karet. Sistem eksentris dengan menggunaan pegas dan konstruksi lebih tinggi sehingga memudahkan pada sistem pengumpulan ladanya.

\section{b. Konstruksi dengan 2 roll.}

Konstruksi yang dibentuk pada alternatif ini menggunakan 2 buah rol penggilas sehingga lada hanya mengalami satu proses perontokan saja. Lada yang terontok langsung turun ke meja saring. Pada sistem ini kurang efektif karena lada yang terontok tangkainya patah. Konstruksi kaki rendah, sehingga sulit dalam pengumpulan hasil lada.

Untuk memilih konsep produk yang terbaik dari beberapa konsep produk yang dibuat digunakan metode dengan menggunakan matriks keputusan. Setiap alternatif konsep produk diberikan nilai. Dari penilaian tersebut, konsep produk yang dipilih adalah konsep produk yang memiliki nilai tertinggi.
]Tabel 3.4 Matriks keputusan

\begin{tabular}{|c|c|c|c|c|c|}
\hline \multirow{2}{*}{ No } & \multirow{2}{*}{ Kriteria } & \multirow{2}{*}{$\begin{array}{l}\text { Nilai } \\
\text { max }\end{array}$} & \multicolumn{3}{|c|}{$\begin{array}{l}\text { Alternatif } \\
\text { Konsep }\end{array}$} \\
\hline & & & $\begin{array}{l}\mathrm{K}- \\
1\end{array}$ & $\begin{array}{l}\mathrm{K}- \\
2\end{array}$ & $\begin{array}{l}\mathrm{K}- \\
3\end{array}$ \\
\hline 1 & $\begin{array}{l}\text { Penggunaan } \\
\text { energi }\end{array}$ & 5 & 5 & 5 & 5 \\
\hline 2 & $\begin{array}{l}\text { Kuat dan tahan } \\
\text { lama }\end{array}$ & 5 & 5 & 5 & 4 \\
\hline 3 & $\begin{array}{l}\text { Kemampuan } \\
\text { merontok }\end{array}$ & 5 & 5 & 4 & 4 \\
\hline 4 & $\begin{array}{l}\text { Harga yang } \\
\text { murah }\end{array}$ & 4 & 3 & 2 & 1 \\
\hline 5 & $\begin{array}{l}\text { Pembuatan } \\
\text { mudah }\end{array}$ & 4 & 3 & 3 & 1 \\
\hline 6 & $\begin{array}{l}\text { Pengoperasian } \\
\text { mudah }\end{array}$ & 5 & 5 & 5 & 5 \\
\hline
\end{tabular}




\begin{tabular}{|l|l|l|l|l|l|}
\hline No & Kriteria & \multirow{2}{*}{$\begin{array}{l}\text { Nilai } \\
\text { max }\end{array}$} & $\begin{array}{l}\text { Alternatif } \\
\text { Konsep }\end{array}$ & 3 & 2 \\
\cline { 4 - 6 } 9 & $\begin{array}{l}\text { Kistem } \\
\text { output } \\
\text { mudah }\end{array}$ & $\mathbf{4}$ & 3 & $\begin{array}{l}\text { K- } \\
2\end{array}$ & $\begin{array}{l}\text { K- } \\
3\end{array}$ \\
\hline 10 & $\begin{array}{l}\text { Jumlah } \\
\text { komponen } \\
\text { sedikit }\end{array}$ & $\mathbf{5}$ & 4 & 4 & 3 \\
\hline \multicolumn{2}{|l}{ JUMLAH } & $\mathbf{4 6}$ & 40 & 38 & 31 \\
\hline
\end{tabular}

Keterangan Objektif yang dipilih:

1. Penggunaan energi: pada setiap konsep diinginkan penyerapan energi besar sedangkan energi yang diperlukan sedikit mungkin

2. Kuat dan tahan lama: setiap konsep diinginkan kuat dan tahan lama. Hal ini untuk mengurangi biaya perawatan dan perbaikan.

3. Kemampuan merontok tangkai lada: diinginkan pada tiap konsep dapat memisahkan lada dari tangkainya semaksimal mungkin dengan proses yang cepat.

4. Harga yang murah: diinginkan biaya yang dikeluarkan untuk penyediaan material serendah mungkin.

5. Proses pembuatan mudah: setiap konsep diinginkan pembuatan yang bisa dikerjakan pada mesin yang tersedia di bengkel.

6. Pengoperasian mudah: diinginkan pengoperasian pada alat dapat dilakukan dengan mudah oleh para pengguna.

7. Waktu perontokkan cepat: diinginkan pada saat pengoperasian waktu yang dibutuhkan secepat mungkin untuk mempercepat proses produksi.

8. Pemasangan mudah: pada setiap konsep diinginkan mudah dalam pemasangan alat agar tidak menyulitkan para pengguna mesin.

9. Sistem Output mudah: setiap konsep diinginkan pengeluaran hasil lada dan sisa dari proses permesinan mudah dan ramah lingkungan.

10. Komponen yang sedikit: tiap konsep yang dipilih diinginkan memiliki komponen yang seminimal mungkin untuk mempermudah perakitan serta biaya pembuatan yang murah.

Berdasarkan kriteria diatas, maka mesin Perontok Tangkai Lada dengan alternatif konsep pertama memiliki point yang paling besar sehingga perancang menilai mesin ini layak digunakan meskipun memiliki point yang tidak terlalu jauh dari alternatif lain.

Penentuan jumlah putaran yang dibutuhkan pada poros perontok (n2)

Berdasar pada tuntutan 30-40 kg/jam, dihitung putaran untuk merontokkan tangkai lada.Kapasitas: $\quad 30-40 \mathrm{~kg} / \mathrm{jam}$, Jadi kapasitas per menitnya adalah $\frac{40 \mathrm{~kg}}{60}$ $=0,67 \mathrm{~kg} / \mathrm{menit}$

Untuk mendapatkan jumlah putaran pada poros perontok dilakukan uji coba mengukur berat satu buah tangkai lada yang ditimbang dan di rata-rata

Hasil uji coba: Berat 1 buah tangkai lada $=$ \pm 1 gram, jadi $4 \mathrm{~kg}$ lada $=4 \times 1=4000$ gram

Jumlah karet perontok $=30$ buah

Jadi, putaran pada poros perontok $\left(\mathrm{n}_{2}\right)$ yaitu:

$=\frac{\begin{array}{c}n \\ \text { Jumlahladayangdirontok }\end{array}}{\text { Jumlahkaretperontok }}=\frac{4000}{30}=$ $133,3 \approx 140 \mathrm{Rpm}$

(3.1)

\section{Penentuan motor yang akan digunakan} Data yang diketahui: $\mathrm{n}_{2}=140 \mathrm{Rpm}$ Untuk mendapatkan putaran yang sama dengan kebutuhan sangatlah sulit, maka dari itu dicari putaran motor yang mendekati dengan kebutuhan. Berdasarkan survei, putaran motor yang tersedia dipasaran yang mendukung dengan kebutuhan adalah : 


$$
\begin{aligned}
& \text { Putaran }\left(\mathrm{n}_{1)}=\quad 1400 \mathrm{rpm}\right. \\
& \text { ratio yang digunakan } \\
& \frac{\mathrm{n}_{1}}{\mathrm{n}_{2}}=\frac{1400}{140}=10 \\
&
\end{aligned}
$$

Berdasarkan ratio yang ada dapat dicari asumsi momen puntir dan daya yang akan digunakan, yaitu: $\quad \frac{\mathrm{Mp}_{1}}{\mathrm{Mp}_{2}}$

$$
\begin{aligned}
& =\frac{1}{10} \text { maka, } \quad \mathrm{Mp}_{1}=\frac{\mathrm{Mp}_{\max }}{10} \\
& =\frac{5577}{10}=557 \mathrm{Nmm}=0,557 \mathrm{Nm}, \\
& \mathrm{P}=\frac{\mathrm{Mp}_{1} \cdot \mathrm{n}_{1}}{9550}=\frac{0,557 \times 1400}{9550}= \\
& 0,082 \mathrm{kw}=82 \mathrm{watt}
\end{aligned}
$$

Diketahui bahwa $1 \mathrm{pk}=746$ watt, dan 3/4 $\mathrm{pk}=550$ watt

Jadi 82 watt $<550$ watt ( Aman ) --$>$ motor $3 / 4 \mathrm{pk}$
Juga dengan pertimbangan momen puntir yang besar.Jadi motor yang digunakan adalah $3 / 4$ pk dengan spesifikasi:Putaran $\left(\mathrm{n}_{1}\right)=1400$ rpm, Daya motor $(\mathrm{P})=550$ watt.Momen puntir $\left(\mathrm{Mp}_{1}\right)=$ $9550 \times \frac{\mathrm{P}}{\mathrm{n}_{1}} \quad=9550 \times \frac{0,550}{1400}=$ $3,752 \mathrm{Nm}$

\subsection{Proses Manufakturing dan Assembling}

Pembuatan bagian-bagian(parts) untuk mesin perontok tangkai ladadilakukan berdasarkan gambar kerja yang telah dibuat. Berbagai mesin manufaktur seperti mesin las, mesin bubut, mesin frais, mesin pembentukan pelat dan lain-lain. Setelah proses pembuatan rangka utama dan part

\begin{tabular}{|c|c|c|c|c|c|c|c|c|}
\hline & & & nual & & & & & Mesin \\
\hline $\begin{array}{r}\text { Denga } \\
\text { (sebelum }\end{array}$ & $\begin{array}{l}\text { angan } \\
\text { (rendam) }\end{array}$ & & & $\begin{array}{l}\text { ah dire } \\
\text { gunaka }\end{array}$ & $\begin{array}{l}\text { am } \\
\text { air ) }\end{array}$ & & & $\begin{array}{l}\text { ebelum } \\
\text { rendam }\end{array}$ \\
\hline kapasitas & waktu & $\begin{array}{l}\text { Kapasi } \\
\text { tas }\end{array}$ & 2hari & 4hari & 6hari & 9 hari & & waktu \\
\hline $1 \mathrm{~kg}$ & 11 menit & $1 \mathrm{~kg}$ & $8 \mathrm{mnt}$ & $5 \mathrm{mnt}$ & $2 \mathrm{mnt}$ & $1 \mathrm{mnt}$ & $1 \mathrm{~kg}$ & 1,2 menit \\
\hline & & & & & & & $2 \mathrm{~kg}$ & 1,5 menit \\
\hline & & & & & & & $3 \mathrm{~kg}$ & 2 menit \\
\hline & & & & & & & $4 \mathrm{~kg}$ & 3 menit \\
\hline
\end{tabular}
selesai, dilakukan proses perakitan sesuai konsep yang telah direncanakan dan gambar assembling yang telah dibuat hingga menjadi sebuah mesin yang utuh.

\subsection{Hasil uji coba}

Berikut tabel hasil proses uji coba :

Tabel 3.5. Perbandingan hasil percobaan secara mesin dan manual

Rata- rata pengukuran $=\frac{\text { Kapasitas total }}{\text { waktu total }}=\frac{1+2+3+4}{1,2+1,5+2+3}=\frac{10}{7,7}=1,2 \mathrm{~kg} /$ menit

\section{Perbandingan volume wadah}

Perbandingan ukuran volume lada dalam $1 \mathrm{~kg}$ pada saat sebelum dirontokkan dan sesudah dirontokkan menggunakan wadah dengan ukuran $20 \times 12 \times 6 \mathrm{~cm}$, sehingga disimpulkan bahwa volume lada hasil adalah $3 / 4$ dari volume wadah sebelum dirontokkan. 
Tabel 3.6 Perbandingan hasil percobaan kapasitas (volume)

\begin{tabular}{ll}
\hline Sebelum dirontokkan & Setelah dirontokkan \\
\hline Melebihi kapasitas wadah1 $\mathrm{kg}$ & 3 is isi wadah . berat lada $7 \mathrm{ons}$ \\
\hline & \\
Sebelum dirontokkan & Setelah dirontokkan \\
\hline
\end{tabular}

\section{Analisa pada mesin}

Dari percobaan yang dilakukan mesin dapat merontokkan lada $80 \%$, tetapi didalam melakukan pemisahan tangkai lada hasil tidak sesuai keinginan dikarenakan struktur tangkai lada berserat mengakibatkan tangkai berhenti disaringan dan mengakibatkan saringan keluar buntu serta putaran untuk eksentrik kurang tinggi sehingga tangkai sulit turun.

\section{SIMPULAN DAN SARAN}

Dari hasil uji coba yang dilakukan pada mesin perontok tangkai lada didapatkan kesimpulan bahwa proses perontokkan yang selama ini dilakukan secara manual membutuhkan waktu cukup lama. Efisiensi waktu perontokkan bisa mencapai $40 \mathrm{~kg}$ perjam,dimana bila diperbandingan antara manual terhadap mesin mencapai $1: 8$ serta meningkatkan efisiensi penggunaan karung dalam penyimpanan lada mencapai 30\%, dimana buah telah terpisah dari tangkainya sehingga dapat memadatkan volume karung secara maksimal.

\section{DAFTAR PUSTAKA}

Awan05, Bantalan Bearing, diakses pada 15 Juni 2011, <http://awan05.blogspot.com/2009/ 12/bantalan-bearing>.
G. Niemann, (1994), Elemen Mesin Jilid 1, Erlangga, Jakarta.

George M. Scott, (1991), Jogiyanto HM tahun, pp196

Mechinenasa, Proses Perancangan Produk, diakses pada 15 Juni 2011, $<$ http://mechinenasa. blogspot.com/2011/05/prosesperancangan produk.html>.

Polman Timah, (1996), Alignment, Politeknik Manufaktur Timah, Bangka.

Polman Timah, (1996), Elemen Mesin 14Politeknik Manufaktur Timah, Bangka.

Scribd, Mesin Arus Bolak-Balik, diakses pada $15 \quad$ Juni 2011 <http://www.scribd.com/doc/40571 015/Mesin-Arus-Bolak-balik>.

Sularso, Kiyokatsu Suga, (2004), Dasar Perancangan dan Pemilihan Elemen, Jakarta, pp.10143. 